\title{
GERMANY'S PAST IN THE THIRD GENERATION FICTION (M. BEYER, FLUGHUNDE)
}

\section{Pomohaibo J. A.}

\section{INTRODUCTION}

Writers, painters, cinema and theatre producers have been turning to Germany`s national-socialist Past so often in their art that this theme tends to be taken today not only as a dominant one in the social-political discourse but also as a recognized national product or a "Made in Germany" trademark. Such interpretation, both ironic and utilitarian, of this rather grave theme belongs to the historian Harald Welzer, and it seems quite in place nowadays. Comic series featuring Hitler and the Holocaust, comedies with a Third Reich plot have indeed become popular export items. Now that the XXI ${ }^{\text {st }}$ century has already begun and more than 70 years have passed since the tragic historical events, world public continues to admire reading books and watching films in which new versions of German history of 1930s - 1940s are offered. The public interest is supported by high sale volumes, international recognition and critical acclaim. Here come to mind the films "Life is Beautiful" by R. Benigni and C. Tarantino`s "Inglorious Bastards “, Z. Liberas`s extraordinary art-project a Lego concentration camp (1996) or a recent screen version of T. Vermes`s bestseller novel “Look Who’s Back” (2012), a story about Hitler`s adventures when he wakes up from lethargy and finds himself in modern Berlin. It appears that exploiting the theme links with German national-socialism becomes a pledge warranting that the product will surely succeed. In this respect the freer is author`s treatment of the topic, the more shocking is his style, the higher will be interest of the public. At this point questions arise: can we assume on this basis that the Past has already been overcome and done away with? Is the currently popular game-and-comedy mode of interpreting the Past the sign of Vergangenheitsbewältigung? To answer these questions, we'll tentatively follow the changes occurring in Germany in seeing the past (and along with that, changes in literature on this theme). Then we'll undertake analyzing M. Beyer`s novel Flughunde which presents the third generation`s position on the events in German history.

\section{Vergangenheitsbewältigung in the post-war social discourse}

To start with, we'll define that "the Past" (Vergangenheit) is usually understood as a dark page in the history of Germany - the epoch of the Third Reich and the Second World War. In the 1990s after the fall of Berlin wall and unification of two Germanies, the notion of the Past gradually incorporated the 
so-called "new history" of Germany as well. The theme of the Past attracts both old generation writers (G. Grass, M. Walser, H. Böll, W. Kempowski, R. Klüger) and the young generation (M. Beyer, B. Schlink, M. Biller and others). While the two generations are at one as to evaluating the nation`s Past (mass murders committed by Nazis are condemned by all without exception as crime against humanity), the question of national guilt sounds more hushed-up with young writers and undergoes rethinking from modern positions.

The writings doing, as T. Adorno put it, "working through the Past" (Verarbeitung der Vergangenheit) and raising questions of collective guilt and responsibility are conventionally grouped in the notion Literatur der Vergangenheitsbewältigung (literature of overcoming the Past), whereas what has been written after 1990 fits more accurately the definition Erinnerungsliteratur (memory literature) as it is based not on authentic evidence given by witnesses but rather on fictionalized recollection concepts ${ }^{1}$, though it should be noted that there is no distinct differentiation of these notions in scientific literature.

The first to use the word-combination "overcoming the Past" was FRG 's President Theodore Heuss (1949-1959) who declared in the first post-war years that it was necessary to acknowledge and redeem the guilt. The expression itself which, by the way, if it is used in other languages, refers solely to FRG, contains some contradiction: the past is what has already taken place, therefore it cannot be returned (that is, cannot be overcome). However, despite some inaccuracy and translation problems, the main idea of this notion is obvious: "The consequences of national-socialist (or any other) dictatorship in all its forms must be overcome" (my translation from German) ${ }^{2}$.

According to German historian E. Jesse, "overcoming the Past” in Germany was taking place on several levels: legal (trials, criminal proceedings), financial (paying compensations) and social (public opposition to the dictatorship, historical investigative research, working through the Past in literature and art). Referring to the situation in Germany after 1990, he uses the concept "double overcoming", pointing at parallels existing between fascist ("brown") and communist ("red") dictatorships. Of course, these two systems cannot be fully equaled (there were no mass murders in GDR as there had been in the Third Reich) but it is obvious that they had much in common: "Both systems concealed the greatest crimes" ${ }^{3}$.

It should be admitted that the Germans`attitude to their bygone has been gradually changing since 1945. Nuremberg trials (International War Tribunal in 1945-1946 and 12 subsequent trials held by the American War Tribunal) gave

${ }^{1}$ Herrmann M. Vergangenheit. Erzählen von Nationalsozialismus in der deutschen Literatur seit den neunziger Jahren. Würzburg, 2010. S. 18.

${ }^{2}$ Jesse E. Doppelte Vergangenheitsbewältigung in Deutschland. Vergangenheitsbewältigung. Berlin, 1997. S. 12.

${ }^{3}$ Ebd. S. 22. 
the start to the active "working through the Past". In spite of the public character of the trials which were expected to re-educate the Germans, they reacted to them either "with apathy or with negative emotions". The public opinion was reduced to the following: "All these goings-on is nothing but winners judging the losers" ${ }^{4}$. On the whole, "most people were not self-critical in their conscience: they were skeptical to those who had resisted the Third Reich regime which was not condemned as criminal by the majority" ${ }^{5}$. After the war they made efforts not to recall what had been done. T. Adorno wrote in 1959 that the intention of "working through the past" is to close the books on

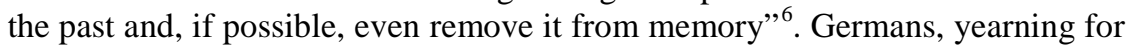
material and spiritual renaissance, were forgetting that they had been involved in the national-socialism.

In 1959 T. Adorno read a lecture The Meaning of Working Through the Past? (Was bedeutet: Aufarbeitung der Vergangenheit?), in which he declared that the course taken after the war toward "overcoming the Past" had not brought the desired results. He stated that fascism was alive, that "the ambiguous figures" who had had key positions in the Third Reich came back to power in democratic Germany. People prefer not to speak about the Past: "We all are also familiar with the readiness today to deny or minimize what happened - no matter how difficult it is to comprehend that people feel no shame in arguing that it was at most only five and not six million Jews who were gassed. Furthermore, the quite common move of drawing up a balance sheet of guilt is irrational, as though Dresden compensated for Auschwitz" .

The failure of "overcoming the Past", according to Adorno is due to a number of reasons. The first of these is an important foreign factor as that the international politics supported the image of Germany as an enemy of communism. "It appears to justify retrospectively Hitler’s attack against the Soviet Union. Since the Western world essentially defines itself as a unity in its defense against the Russian threat, it looks as though the victors in 1945 had foolishly destroyed the tried and tested bulwark against Bolshevism, only to rebuild it a few years later" 8 .

Second, there exist internal reasons connected with the traits of German character. The scholar goes on: "For countless people life was not at all bad under fascism. Terror's sharp edge was aimed only at a few and relatively well

\footnotetext{
${ }^{4}$ Welzer H. Vergangenheitsüberwältigung. Kultur des Erinnerns. Vergangenheitsbewältigung in Spanien und Deutschland. Frankfurt am Main, 2009.

${ }^{5}$ Jesse E. Doppelte Vergangenheitsbewältigung in Deutschland. S. 13.

${ }^{6}$ Adorno T. The Meaning of Working Through the Past. Critical Models: Interventions and Catchwords. New York, 2005. P. 89-103. URL: https://signale.cornell.edu/text/meaning-workingthrough-past.

${ }^{7}$ Ibid.

${ }^{8}$ Ibid.
} 
defined groups” ${ }^{9}$. Mostly conformists - in fact helpless and weak people became adherents of the authorities. They felt the need to be part of a large community as they possessed "weak egos". Growth of "collective narcissism" or "national vanity" was the reverse side of national-socialism. T. Adorno comes to conclusion that "working through the Past" must involve critical approach to remembering the Past, "a turn toward the subject, the reinforcement of a person's self-consciousness and hence also of his self" $"$.

A significant transformation in understanding the collective guilt and responsibility has occurred since 1960s. The further were Germans removed from the past events, the greater was the intensity of their attempts to reason the Pastout, that, to a great extent, was due to the consequences of the students revolution ${ }^{11}$. The sign of the seventies was acceptance by Germans of their guilt and collective responsibility. Putting a veil of silence on the Third Reich crimes stopped and recognition of genocide formed the basis of the FRG`s state policy. Later the photo of Bundeskanzler Willie Brandt kneeling before the Holocaust victims 'memorial in Warsaw on December 7, 1970 became the symbol of the changes that had begun. This gesture is still perceived as public recognition of German guilt.

The 1980s saw a dispute among historians (Historikerstreit). It manifested the next stage in understanding the Past and involved a historian Ernst Nolte and a philosopher Jürgen Habermas in an argument in which Nolte raised a question of uniqueness of national-socialism. In his article The Past that does not want to go (Vergangenheit, die nicht vergehen will, newspaper FAZ, 6.06.1989) he wrote that "the past asserts itself as the present and hangs over it as a punishing sword" (my translation from German). To move away from the Past (Nolte used the term "historization"), it should be admitted that similar dictatorships had existed before (for example, Napoleon`s epoch or August`s principality). In this sense national-socialism was not a unique fact of world history. Everything that was done by Nazis (with the exception of gas chambers) had been known in other countries in the 20s and 30s: eviction of peoples, concentration camps, tortures. In his article he wrote that declarations of "collective German guilt resemble declarations of collective guilt of Jews". In general he presented the war of Germany against the USSR as a defensive response to the threat coming from bolshevists ${ }^{12}$. In the opinion of D. Chugunov: "phenomenological approach to studying fascism, suggested by

${ }^{9}$ Adorno T. The Meaning of Working Through the Past. Critical Models: Interventions and Catchwords. New York, 2005. URL: https://signale.cornell.edu/text/meaning-working-through-past.

${ }^{10}$ Ibid.

${ }^{11}$ Jesse E. Doppelte Vergangenheitsbewältigung in Deutschland. Vergangenheitsbewältigung. Berlin, 1997. S. 14.

${ }^{12}$ Nolte E. Die Vergangenheit, die nicht vergehen will. Eine Rede, die geschrieben, aber nicht gehalten werden konnte. Frankfurter Allgemeine. 6.06.1986. URL: http://www.staff.uni-giessen. de/ g31130/PDF/Nationalismus/ErnstNolte.pdf. 
Nolte, resulted in its author being accused short of vindicating Hitler (for instance, by J. Habermas) or of right radicalism and anti-Semitism” (my translation from Russian) ${ }^{13}$.

The major J. Habermas`s argument in the dispute with E. Nolte was that the latter`s presenting Nazis crimes as "response to the Bolshevists` threat of destruction" and reducing Auschwitz to the format of a technical innovation deprived them of their historical "uniqueness". Objecting to historization of Nazis` crimes, Habermas insisted on having to look for Germany`s national identity in "constitutional patriotism" 14 . There was a broad response and heated polemic in the wake of the historians dispute. In D. Chugunuv`s opinion "it was a frank discussion of how evolve political and social ideas, of the meaning in European and World history and, mainly, of whether the foundation of modern German society is still capable of withstanding the formidable weight of the Past. Historians of the "conservative wing" (Nolte, Fest, Hillgruber, Stürmer) were inclined to give a positive answer, Habermas`s "liberal" supporters (Mommsen, Augstein) a negative one. The discussion gradually shifted from sociologists and historians into the realm of literature. Writers were quick in reacting to the public trend to relativize German guilt. There appeared works in which Germans feel they are not criminals but victims of the Third Reich politics (for instance, G. Grass`s short story "Crabwalk”).

The 1990s. Fatigue from being constantly reminded of shame. Everybody expected in 1990s that the German literature would turn over a new leaf. "The end of post-war literature" heralded in after the Turn actually meant the end of being constantly reminded of the Past. Even prestigious writers came up with critical statements in which they insisted on having to stop the obsessive process of overcoming the Past. "Nobody denies Auschwitz", said M. Walser, "but Holocaust has long turned into "a moral bludgeon" (Moralkeule) and "a means of intimidating" (Einschüchterungsmittel). He accused mass media of "prolonged representation of our shame': "Instead of being grateful for continued demonstration of our shame I begin turning away". In his speech he insisted on having to re-examine the attitude to Auschwitz, to be exact, to its "instrumentalization" 15 . It`s noteworthy that though the speech had a provocative character, M. Walser`s thesis met a broad public support.

The years 2000s. The German nation as a victim? At the turn of the $\mathrm{XX}^{\text {th }}-$ $\mathrm{XXI}^{\text {st }}$ centuries the discourse about national-socialism moves into a different plane: now the main question is that of distributing roles between "victims"

13 Чугунов Д. А. Немецкая литература 1990-х: основные тенденции развития: дис. ... докт. филол. наук : 10.01.03. Воронеж, 2006. С. 46.

${ }^{14}$ Habermas J. Eine Art Schadensabwicklung. Die Zeit. 11.07.1986. URL: http://www.zeit.de/ 1986/29/eine-art-schadensabwicklung/.

${ }^{15}$ Walser M. Dankesrede zur Verleihung des Friedenspreises der Deutschen Buchhandels in der Frankfurter Paulskirche. 11.10.1998. URL: http://opus.bsz-bw.de/hdms/volltexte/2005/ 488/pdf/walserRede.pdf.. 
(Opfer) and "criminals" (Täter). The Germans who got used to their role of „criminals“ were offered then to feel that they were victims. It was W.G. Sebald who first proposed such an approach to the Third Reich history in a series of lectures entitled Air War and Literature (Luftkrieg und Literatur) read in Zurich in 1999. He emphasized the absence in German literature of works describing the allied air raids on German towns. In the course of British and American air bombings in 1943, the aim of which was to exterminate peaceful German population, thousands were killed - however the consequences of this "collective trauma" were not reflected in literature. Sebald claimed that the whole generation of German writers was unable to describe and confirm in human memory what they had witnessed"16.

It should be noted that already in 2002 did such a book appear - meaning a documentary book "The Fire” by the publicist and historian Jörg Friedrich. The author focuses on the Germans sufferings caused by British and American moral bombings. Not concealing the fact that the German Air Force was the first to bomb Spain and Poland, he denounces the allied attacks as „barbarous extermination of innocent civilian population“ rather than as a response to enemy`s actions ${ }^{17}$.

V. Hage, arguing with M. Walser, drew attention to the fact that numerous writings about the WWII and the Holocaust actually only "touched" the Past but didn 't thoroughly examine it. This was true regarding the novels by $\mathrm{H}$. Böll, G. Grass, S. Lenz. There are exceptions relating to those authors who passed through ghettos and concentration camps - B. Apitz, J. Becker, R. Klüger, E. Hilsenrath ${ }^{18}$. V. Hage rejects the widespread opinion that the German literature cannot get rid of the Past. He considers that the real post-war literature, speaking openly and freely about the Past, emerges only at the threshold of the new millennium.

The historian G. Welzer criticizes the system of careful, politically correct and at the same time superficial, ritualized treatment of the Past that has taken shape in modern society. Erection of a Holocaust victims memorial in the very centre of Berlin in 2005 became the most "successful project" of such symbolic recognition of the German guilt (Denkmal für die ermordeten Juden Europas or Holocaust-Mahnmal) ${ }^{19}$. Welzer thinks that development of a diplomatic language appropriate for speaking about Nazism and Holocaust does not mean that "overcoming of the Past" has indeed taken place. Young people skillfully use all "ritual formulas" accepted in the society but they secretly admire Hitler. The elder generation`s personal memoirs have an ambivalent character as well.

${ }^{16}$ Sebald W. G. Luftkrieg und Literatur. München; Wien, 1999.

${ }^{17}$ Metzler Literatur Lexikon: Begriffe und Definitionen. Stuttgart, Weimar, 2007. S. 348.

${ }^{18}$ Hage V. Feuer vom Himmel. Der Spiegel. 12.01.1998. URL : http://www.spiegel.de/ spiegel/print/d-7810012.html.

${ }^{19}$ Welzer H. Vergangenheitsüberwältigung. Kultur des Erinnerns. Vergangenheitsbewältigung in Spanien und Deutschland. Frankfurt am Main, 2009. S. 29. 
"On the one hand, they recall the wonderful time when the young people came off the street, when blitzkriegs were won ... on the other hand, family memories revolve around sufferings, calamities, poverty and the home destroyed by bombing...."20.

The contemporary literature of "overcoming the Past" prefers, in Welzer`s opinion, "to advertise the German sufferings" instead of examining their causes. There comes off the printing press a multitude of books in which Germans are portrayed as victims and the German suffering becomes collective memory though not all German population in fact suffered from the war. Welzer asks: "What has been overcome?" and he answers: "Nothing. Quite on the contrary, there is taking place a memorial rollback". Nostalgic elements and admiring the Third Reich are being mixed up to the remembrances of the Past. As the opposite side of the obsession with the Past there comes lack of confidence in the future: "there has never been so much of the Past, neither so little of the future" 21.

Thus, the years 1990s - 2000s usher in a real uprise of interest in the Past, "a real boom of the past" (Vergangenheitsboom) or rising "demand for memories" [Hermann]. The number of books about the Third Reich, Hitler and Holocaust multiplies. Here are some of them - My Century by G. Grass (1999), A Gushing Fountain by M. Walser (1998), The Silent Angel by H. Böll (1992). Among the young representatives of this trend the best known are M. Beyer (The Karnau Tapes, 1995, Kaltenburg, 2005), B. Schlink (The Reader, 1995), J. Franck (The Blindness of the Heart, 2007), U. Tim (In My Brother`s Shadow, 2003).

\section{Understanding the Past in Marcel Beyer`s Novel Flughunde}

Marcel Beyer (1965), poet, essayist and translator, is one of the central figures in contemporary German literary process. As the author of lyrics, fond of experiments, he claimed popularity yet in the late 80s, his creative maturity came in the late 90s - early 2000s. His second novel Flughunde (The Karnau Tapes in English translation) is considered his best known work in which he takes up the theme to become the leading one in all his writings - the Past reflected in the Present. Many of his novels (Das Menschenfleisch, 1991, Spies, 2000 , and others) are reminiscent in varying degrees of the sinister period 1933-1945 but at the same time they reveal the way a modern man looks at those events. One of reviews on his book has pointed out this property of his prose: "Marcel Beyer`s skill consists just in this: writing a novel about a strange collector of sounds in the Third Reich, a book which is an incredibly timely one, being itself an echo of our Present”" ${ }^{22}$. Like B. Schlink, he belongs to the

\footnotetext{
${ }^{20}$ Welzer H. Vergangenheitsüberwältigung. Kultur des Erinnerns. Vergangenheitsbewältigung in Spanien und Deutschland. Frankfurt am Main, 2009. S. 29. S. 30.

${ }^{21}$ Ibid. S. 32.

${ }^{22}$ Marcel Beyer: Flughunde [Rezension]. FAZ. 17.03.2002. URL: http://www.faz.net/aktuell/ feuilleton/buecher/rezensionen/belletristik/rezension-belletristik-marcel-beyer-flughunde152244.html
} 
generation of writers who have studied the Third Reich history not through their personal experience but indirectly as the material to undergo literary processing. The distance of two generations neutralized their feeling of being part of the Past but in no way diminished the theme`s urgent timeliness.

The author defines his understanding of history as "absolute vacuum" (ein völliges Vakuum). His generation lacked "family legends" or fundamental knowledge and "several school lessons in history" of the Third Reich could not fill the gap ${ }^{23}$. The fact is quite odd considering that the post-war silence had already been interrupted and the society was busy doing active research in "white spots" of history (books, TV shows etc.). It is likely that the sense of "vacuum" was felt because this generation had witnessed a new historical event - the Fall of Berlin wall and unification of Germany. The Third Reich history was shadowed by the events of the Turn and had indeed become the Past, a completed stage which now could explain the unresolved conflicts of the Present ${ }^{24}$. This situation enabled the new generation freely to interpret the Past, imagine and rewrite the course of events.

The starting point for Beyer`s fictitious story was a historical fact - the suicide of all Goebbels`s family members in a Berlin bunker on May 1, 1945. Beyer reconstructs the last days of the war, when on the eve of capitulation Joseph and Magda first poisoned their six children and then killed themselves. Besides real historical figures (Hitler, Goebbels and his children), who should be understood as being freely interpreted by the author, the novel has a fictitious hero - the chief acoustics engineer of the Third Reich, a fanatical scientist Herman Karnau who personally knew the Goebbelses and was present in the bunker at the time of their death. Though this hero had a real prototype (a man named Herman Karnau had a rank of Oberscharführer SS, was their security chief and witnessed the Führer`s death). All the rest in the novel was, of course, invention.

In the novel there are two parallel storytellers presenting each his view of the events (principle of antithesis). The scientist`s cool unemotional voice soberly documenting the events is in contrast to a naïve voice of a child - Helga, Goebbels`s elder daughter. In the final pages of the novel the contrast between the perspectives becomes stronger, the "live" voice of the acoustics engineer Karnau, who started a new life in GDR after the war, sounds in sharp discord to the "dead" voice of Helga, who had become a victim of the adult world. The storytellers voice parts alternate, Karnau`s story about his horrible experiments are periodically interrupted with Helga`s childish stories, without violating the chronological sequence of events. Initially, the adult`s and child`s passages are tied up with common tunes (for example, the acoustic "panorama" of the war

${ }^{23}$ Strebin B. Wenn die Stimme die Seele (z)ersetzt ... Marcel Beyer über seinen Roman „Flughunde“. GrauZone. Zeitschrift über neue Literatur. 1995. № 5. S. 15.

${ }^{24}$ Uecker M. «Uns allen steckt etwas von damals in den Knochen». Der Nationalsozialismus als Objekt der Faszination in den Romanen Marcel Beyers. Wende des Erinnerns? Geschichtskonstruktionen in der deutschen Literatur nach 1989. Berlin, 2006. 
shifts into a magnificent "panorama" of the Alps mountains which serves as a background when the Minister's family is being photographed). The two perspectives gradually melt into one whole - in the plot (both heroes are found in the bunker and present their versions of events), and in the style (the two storytellers ' voices are almost indiscernible) ${ }^{25}$. Separate episodes are connected in a way resembling gluing of a film. As a result a reader hears not individual voices but "a single history" (Eine Geschichte), which focuses on "the very fact and horror of what is happening" ${ }^{26}$ rather than on the heroes` lives.

The first part of the novel (chapters 1-6) covers the Past events in the period from 1940 to 1945, and, initially, Karnau presents himself as a common man in the service of the Third Reich. His task is to assure ideal sound quality when speeches are delivered using mikes and all the required equipment. Soon he begins to identify himself with an observer in the shade of large-scale events: when a parade is rehearsed (the first chapter), he is only adjusting the mikes and masking the wires ("Wie Akustiker liegen etwas hinter der Zeit") ${ }^{27}$. At this point the hero s position resembles the conformity principle of Oskar Matzerath, a heroin G. Grass`s novel The Tin Drum - "Always take care to be sitting on the rostrum and never to be standing out in front of it" ${ }^{28}$. The scene of making preparations before the parade is a kind of introduction to the Reich 's acoustic world. Beyer touches an important aspect of the national-socialist ideology sound as a manipulation instrument and the main component of the party`s "voice politics". It is noteworthy that the German National-Socialist Party was, in its essence, "a party of public speakers", its internal structure and political activity were based on vocal powers of its figures ${ }^{29}$. In this sense Karnau`s work was a part of the propaganda system, as it facilitated spreading false ideas.

The real Karnau`s face, hidden behind an acoustics engineer mask, is eventually exposed -he is a mad scientist obsessed with a desire to make an acoustic map which will indicate all possible sound sources.He is particularly interested in those sounds which exceed the "normal" sound limits - groans, screams, death-rattle. To enrich his collection, Karnau first gets to the front-line where he records voices of wounded and dying soldiers, and then as a member of research group he manages horrible experiments on prisoners extracting out of them new voice shades. Only Germany`s capitulation puts an end to a chain of Karnau`s inhuman crimes.

The novel's second part (chapters 7-9) takes the action to the present. A phono-archive was found in a basement of Dresden elderly people`s home in

\footnotetext{
${ }^{25}$ Ostrowicz Ph. A. Die Poetik des Möglichen. Das Verhältnis von „historischer Realität“ und „literarischer Wirklichkeit“ in Marcel Beyers Roman „Flughunde“. Stuttgart, 2005. S. 51.

${ }^{26}$ Ibid. S. 53.

${ }^{27}$ Bayer M. Flughunde. Frankfurt am Main, 1996. S. 12.

${ }^{28}$ Grass G. The Tin Drum / trans. from German by R. Manheim. London, 2004. P. 100.

${ }^{29}$ Epping-Jäger C. Stimmgewalt. Die NSDAP als Rednerpartei. Stimme. Frankfurt am Main, 2006. S. 149.
} 
1992. Its card indexpreserved the name of Herman Karnau, security man. Here in Chapter 7 there appears the third narrative instance - an anonymous storyteller on the part of the third person, who informs about the course of investigation. As a result, it becomes known that thorough conversance of Karnau, who wanted to pass for a guard man, was obviously beyond his status. After it is also revealed that the last operations were performed in the basement just a few days before, Karnau, the suspect, disappears without a trace.

The unreliable narration. The researchers consider that though the narration is made authentic, the readers cannot believe any narrator. Beyer`s novels are written in the way "that the reader, who wants to trust, encounters the narrator making him feel horror" ${ }^{30}$. That Helga is "unreliable" is not only because of her young age (she died when she was 12), but, rather, because of her dual status of a victim. Indeed, Helga was still a kid, but even at this point Beyer is playful, choosing the elder daughter to be a narrator. Even Karnau notices her intelligence, uncharacteristic of her age: "Als wäre Helga schon viel älter, als stünde sie schon auf der Schwelle zum Erwachsenendasein... “31. Her status of a top politician`s child makes Helga still more different from ordinary children. Goebbels`s children had always attracted attention in the Third Reich, Mass Media cultivated the image of the Third Reich model family. This role requires some effort from her ("Dass wir auch immer so lange stehen und freundlich in den Photoapparat lächeln müssen"), however, on the whole, she enjoys this ("Natürlich ist das schön, wenn wir in die Zeitung kommen, meine Klassenkameradinnen bewundern mich dann immer") ${ }^{32}$.

That Helga is not guilty should be put in doubt. To some extent she is also responsible, as she was able to discern lies and deception. While Karnau is an accomplice (Mitläufer), she is initiated, a witness (Mitwisserin). For instance, she knows about her father`s secret mistress, that he arranged for a shadowing on her mother, she exposes the Werewolf stories as an adults`invention. She does not yield to emotional influence of the propaganda: during the Goebbels`s famous speech in the Sports Palace she impassively watches what is going on. Thus, Uker concludes that "Goebbels`s children are shown as innocent, unreceptive to the national-socialist ideology"33.

It is a peculiar feature of the novel that there is no moralizing line in it that was not characteristic of "the first generation" literature. On the one hand, Karnau is shown as a criminal, on the other hand, as a private man, calling for

${ }^{30}$ Simon U. Assoziation und Authentizität. Warum Marcel Beyers Flughunde auch ein Holocaust-Roman ist. Auskünfte von und über Marcel Beyer. Fußnoten zur Literatur. 2003. Heft 46.

${ }^{31}$ Bayer M. Flughunde [Roman]. Frankfurt am Main: Suhrkamp, 1996. S. 56.

${ }^{32}$ Ebid. S. 120.

${ }^{33}$ Uecker M. «Uns allen steckt etwas von damals in den Knochen». Der Nationalsozialismus als Objekt der Faszination in den Romanen Marcel Beyers. Wende des Erinnerns? Geschichtskonstruktionen in der deutschen Literatur nach 1989 [B. Beßlich, K. Grätz, O. Hildebrand]. Berlin: Erich Schmidt Verlag, 2006. S. 59. 
sympathy and confidence. This second (pseudo-humanistic) side of Karnau`s nature is revealed through Helga`s scant estimate: "Vielleicht ist Herr Karnau ja gar nicht so seltsam, wie ich am Anfang dachte. Jedensfalls wird er langsam netter und kümmert sich nicht mehr nur um die Kleinen" ${ }^{34}$. "The new daddy`s acquaintance” gradually wins over the children`s confidence and becomes their solicitous friend, who brightens the last days of the children`s life.

Karnau `s principle of "unreliable narration" consists in imitating a victim`s voice. He intentionally confuses the reader, presenting himself first as an opponent of Nazi ideology and afterwards he turns out to be an accessory to the crime and every time he keeps silent about his guilt and becomes transformed into an inconspicuous "man without qualities". In the very beginning of the novel Karnau is shown as a man not having an individuality: "Ich bin ein Mensch, über den es nichts zu berichten gibt. [...] Ein Mensch wie ein Stück Blindband, das vor Anfang des beschichteten Tonbands angeklebt ist.... ${ }^{35}$. It becomes clear only at the end of the first chapter that losing an individuality became the strategy required for a criminal to survive in the post-war Germany. The Führer`s doctor and Karnau`s colleague Stumpfecker said: Vordringlichste Aufgabe ist es nun, wie ein Opfer sprechen zu lernen [...] Verschweigen Sie Ihre Tätigkeit der letzten Jahre, indem Sie diese Pausen zögerlich ansteuern in Ihren Bericht. Verstummen Sie dann aber rechtzeitig, um nichts von Ihrer Tätigkeit preiszugeben”36. Now the whole Karnau`s story is read as a successful staging of a victim`s role.

The only property that makes Karnau different from others is his susceptibility to sounds. He is close to Suskind`s olfactory hero who perceived the world as all diversity of smells. Karnau senses all surrounding sounds and he can get rid of jarring sounds only by making them part of his collection (that is by acquiring power over them). As Grenouille did not have his own smell, Karnau does not hear his own voice. That is how Beyer creates an image of a "living corpse" - a man having no identity, a man in whom fascism atrophied all living senses.

Collector and pseudo-scientist. The dominant trait in the collector`s behavior becomes his being incapable of recognizing the Other, his dying numbness of all human senses or "moral exclusion" "37. This explains Karnau`s aggressive, proprietary attitude to people. For him they are nothing but "signifiers" in his collection, elements of his acoustic atlas. Any experiments on people are justified by scientific objectives and taken as lawful. For him as a researcher, a pure source of sound is not a tormented man who needs immediate help: "Die Schalquelle, welche in diesem Moment für den Hörer nur genau dies

\footnotetext{
${ }^{34}$ Bayer M. Flughunde [Roman]. Frankfurt am Main: Suhrkamp, 1996. S. 56.

${ }^{35}$ Bayer M. Flughunde. Frankfurt am Main, 1996. S. 16-17.

${ }^{36}$ Ebid. S. 215.

${ }^{37}$ Кучумова Г.В. Роман в системе культурных парадигм (на материале немецкоязычного романа 1980-2000 гг.) : дис. ... докт. филол. наук : 10.01.08. Самара, 2010. С. 200.
} 
eine sein darf, Schallquelle, nicht etwa ein Mensch mit Schmerzen, dem es zur Hilfe zu eilen hat" ${ }^{38}$.

Karnau is consistently putting his plan into practice. He first studies the theory, then acquires the knacks on horse skulls, learning the structure of vocal organs. At this stage he is even governed by a certain ethical code which he will never have the nerve to break: "Die Stimmen dieser Kinder werden auf meiner Karte nicht verzeichnet, wo sie dann offenlägen vor aller Welt, und, schlimmer noch, auch vor den Kindern selber“39. Here Beyer also touches an urgent theme of ethical boundaries in scientific research, a theme which has a number of times been examined in the $\mathrm{XX}^{\text {th }}$ century German literature (B. Brecht's "Galileo Galilei”, F. Dürrenmatt`s "The Physicist”). Having studied all the sounds available in the town, the hero expands the research geography. He sets out for Strasbourg occupied by the Germans, where there starts a campaign to germanize the town. The cost of getting access to new sounds is collaboration with the Nazis.

At the frontline a new acoustic panorama becomes available. Facing death, of which he is not yet guilty, Karnau justifies himself that he is not a criminal, not a murderer, but only a kind of "thief". He has the power to use at his own discretion the last sounds of dying people. The final deformation of his personality takes place when he participates in a research group and begins experimenting on living people. Doing that, he looks on them as some guinea pigs, impersonalized, effaced creatures sacrificed for a supreme mission. B. Beßling considers that Karnau describes his sinister experiments unemotionally, matter-of-factly, and avoids referring to the first person, himself. His "self" hides behind impersonal sentences, for instance: "Die Versuchspersonen werden wachgeschlagen. Leuchten Sie in den Raum. Nur noch die Silhouetten der Figuren “40. The more Karnau evades responsibility, the more he conceals his guilt, the more appealing becomes the text offering the reader to make a moral choice by himself.This Karnau`s pseudo-ethical position gives way as a result - in the final episodes of the novel the dying children`s voices fill the gap as exhibits in his collection.

The original novel`s title Flughunde is a symbol of subtle and imperceptible world that is reminiscent of Karnau` childhood when he could examine the album photographs of these exotic creatures for hours on end. It impressed him that these small animals were active at night when their sight was impaired and they had touse sound for orientation. Karnau, too, leads night life, the night world becomes his refuge giving him the sense of security and being hidden ${ }^{41}$. His admiring flying dogs inspired him to study the world of sounds. However,

\footnotetext{
${ }^{38}$ Bayer M. Flughunde. Frankfurt am Main, 1996. S. 29.

${ }^{39}$ Ebid. S. 63.

${ }^{40}$ Ebid. S. 170.

${ }^{41}$ Роганова И. С. Исторические ракурсы в немецкоязычной литературе конца XX века.
} M., 2007. C. 40. 
he did not take into account that human hearing potential was not infinite and there was another sound dimension - the ultrasonic - which he would never have access to and would never be able to put on a map. His map would always remain imperfect as the communication means of cheiroptera was beyond human power. For Karnau it meant that his scientific project was a failure.

History and fiction. Combination of historical and fictitious narrative elements is one of the most interesting aspects of the novel. H. Karasek named the book`s "narrative truth” (erzählerische Wahrheit) to be its greatest asset ${ }^{42}$. B. Künzig`s opinion is that the book`s authentic effect arises because the author did not set himself the task to attach authenticity to the events described but invented his new "form of truth", suggesting one of history`s numerous probable versions considering the experience of preceding generations ${ }^{43}$.

Such a free treatment of historical material is one of the attributes of postmodernist literature. The novel begins the "truth and fiction" game with the epigraph: "Ich höre die süßen Stimmchen, die mir das Lieste auf der Welt sind. Welch ein Schatz, welch ein Besitz! Gott erhalte ihn mir!"44. A reader learns at the very end of the novel that this utterance is in fact a Goebbels`s actual entry in his diary of 20.04.41. Also here in his final remark does the author confess that his story is an invention.

In his monograph "Poetics of the Possible" P. Osctrowitz examines the novel as a synthesis of "historical reality" and "literary reality" which supplement one another rather than exclude. "Historical reality" embraces different methods of presenting it, based on facts of history (they can be historiography, documentary literature), whereas "literary reality" is a world imagined, invented by the author ${ }^{45}$. Both discourses contain elements of truth and imagination and are found in permanent reciprocity. The novel`s artistic world broadens perception of historical reality and can be understood as its continuation.

Mass Media discourse. Besides being a fictitious document of the Past, the Flughunde is also a novel suggesting a discussion with modern mediadiscourse. G. Kuchumova argues that the novel dethrones the human omnipotence myth, the myth of man`s becoming a demiurge ${ }^{46}$. The novel contains numerous allusions to post-modernist conceptions of Jean Baudrillard, Marshall McLuhan, the works of the German electronic media theoretician Friedrich Kittler. The novel`s hero propounds his own theory according to

${ }^{42}$ Karasek H. Schreien und Flüstern. Helmut Karasek über Marcel Beyers Roman «Flughunde». Der Spiegel. 03.07.1995. URL : http://www.spiegel.de/spiegel/print/d-9201442.html.

${ }^{43}$ Künzig B. Schreie und Flüstern - Marcel Beyers "Flughunde". Baustelle Gegenwartsliteratur. Die neunziger Jahre. Opladen/Wiesbaden, 1998. S. 123.

${ }^{44}$ Bayer M. Flughunde. Frankfurt am Main, 1996. S. 4.

${ }^{45}$ Ostrowicz Ph. A. Die Poetik des Möglichen. Das Verhältnis von „historischer Realität“ und „literarischer Wirklichkeit“ in Marcel Beyers Roman „Flughunde“. Stuttgart, 2005. S. 17-18.

${ }^{46}$ Кучумова Г.В. Роман в системе культурных парадигм (на материале немецкоязычного романа 1980-2000 гг.) : дис. ... докт. филол. наук : 10.01.08. Самара, 2010. С. 193. 
which man yields his place to a tape-recorded sound. Künzig says that Karnau is anembodiment of a post-modernist project in which magnetic tape-recorded reality or reality preserved on electronic (or technical) carriers becomes more real than actual life ${ }^{47}$. The problem Beyer raises is in harmony with the postmodernist ideas of an individual's death in the epoch of technical reproductivity. Human existence has been put in doubt, since it became possible to preserve and play back human images by photo cameras, video and audio devices. That's why recording the children`s voices is the same for Karnau as their dying, and he wants to protect them from an awful experience of alienation he himself once experienced. An acoustic image does not coincide with an actual human image, diverges from its inner essence. His instinctive fear of death explains his reluctance to record his own voice: "Wird dem Menschen mit jedem konservierten Laut ein, wenn auch nu rein geringer, Bruchteil seiner Stimme gestohlen? ${ }^{48}$ " G. Kuchumova points out that "an alienated sound loses its individuality, its being inimitable and unique, and becomes enough abstract so that then an archive or collection owner could experience an abstract feeling of possession listening to it" 49 .

The first reality is gradually ousted and consumed by the second. G. Kuchumova suggests that in his acoustic cognition of the world Karnau moves from "poetical” perception of the world to a "technical man`s" alienated view $^{50}$. Initially, Karnau does not have the nerve to record the children`s voices, but later his naïve desire to retain "white spots" on the acoustic map gives way to a wish of appropriating their voices. That's how Karnau becomes their "murderer" taking their voices away. However, he is not to be made answerable for this at all, because real murder is replaced with its medial representation, and as a voice substitutes physical reality, a murder has not taken place (from Karnau`s point of view).

Mass media is not exclusive in manipulating man: Karnau shares a manipulator role with it, invading acoustic space, a world of "fractal subjects" existing outside reality. Here Beyer refers to J. Baudrillard and M. MacLuhan`s thesis of "man`s expanding" into medial worlds which are torn away from man`s physical space. Karnau`s experiments may be interpreted to be an invasion into man`s nature, destruction of physical body and its substitution with a medial image. A body is an obstacle for a voice which must be let free ${ }^{51}$.

${ }^{47}$ Künzig B. Schreie und Flüstern - Marcel Beyers «Flughunde». Baustelle Gegenwartsliteratur. Die neunziger Jahre. Opladen/Wiesbaden, 1998. S. 136.

${ }^{48}$ Bayer M. Flughunde. Frankfurt am Main, 1996. S. 93.

49 Кучумова Г.В. Роман в системе культурных парадигм (на материале немецкоязычного романа 1980-2000 гг.) : дис. ... докт. филол. наук : 10.01.08. Самара, 2010. С. 194.

${ }^{50}$ Там же. C. 197.

${ }^{51}$ Künzig B. Schreie und Flüstern - Marcel Beyers «Flughunde». Baustelle Gegenwartsliteratur. Die neunziger Jahre. Opladen/Wiesbaden, 1998. S.137. 
Is it possible to extract a man`s voice which thus will become veritable and true, not a distorted reflection of his essence, his ego? In his sleep Karnau dreamed of an experiment in which he was a subject experimented on. Doctors cutting his scalp put a gramophone needle on the cranial suture having the shape of sound track. The aim of the experiment was to extract man s true sound, "the protosound" combining both acoustic and real man`s images. Karnau `s dream represents an intertextual reference to R.M. Rilke`s short story "The Primal Sound" (1919). This "sequence of sounds", this skull music symbolizes, in Rilke`s view, synesthesia, a certain "paralanguage" which is beyond the visually perceived world. The image of primal sound combining everything that is known and everything that cannot be known in one point becomes a starting point for reflections about poetry and the poet's goals whether art can compete with technology or a poet with an inventor? Technical achievements (phonograph, microscope and telescope) open up new vista of perception to which man did not have access before, but this "expansion" of separate perception areas do not mean sensuous cognition experienced by an individual ${ }^{52}$. The poet, according to Rilke, must constantly broaden the boundaries of sensuous perception and use all his sense organs. Only then will he be able to succeed in mastering new perception zones, which, however, cannot be plotted on a "common map".

\section{CONSCLUSIONS}

Considering the sense Rilke put in his "primal sound" notion, Beyer`s novel is indeed a "synesthetic" product making broader the writing potentials. The novel has no active characters -instead of personages are offered "voices', i.e. their derivatives - the counterfeits simulating reality. In fact, Beyer`s novel imitates "non-symbolic communication" aided by the use of a phonograph and a gramophone. There is similarity in the way a phonograph records sounds without interpreting and evaluating them, and the way Karnau reproduces through his narration the awful events without being held accountable for them.

It is obvious that the novel whose leading motif was a tape-recorded voice can be also read as one emphasizing the impact of media and technology-based environment on the life of an individual. M. Beyer shows the myth of man`s omnipotence to be untenable, even though thanks to information technologies man began to feel he is a demiurge.

Interpretation of history in the writing of Marcel Beyer as a "third" postwar generation representative has been shown to be subjective and ambivalent in full accord with the principal postmodernist trend. Playful approach to historical facts, myth fictionalizing and deconstruction are characteristic of his novel. The novel`s analysis has demonstrated how the past is becoming a game space for "escaping" from the dim chaos of social-historical relations.

${ }^{52}$ Rilke R. M. : Werke in 3 Bänden. Frankfurt am Main : Insel Verlag, 1966. Band 3. Prosa. S. 550. 


\section{SUMMARY}

The article deals with the problem of interpreting the Past in the novel Flughunde (1995) by M. Beyer. The author of the novel is considered to be the famous representative of the Third post-war Generation of writers. The time distance between the Nazi period and the present time allowed them to fictionalize the history and to fabulate freely. The first part of the research article investigates the changes in the perception of the Past from the immediate post-war time to the present. In the second part the novel Flughunde is being analyzed from the perspective of the Third generation. It is shown that Beyer`s interpretation of history combines historical facts with fictitious narrative elements. The novel demonstrates the playful, subjective and ambivalent approach to Germany`s past as typical for contemporary German writers.

\section{REFERENCES}

1. Кучумова Г.В. Роман в системе культурных парадигм (на материале немецкоязычного романа 1980 - 2000 гг.) : дис. ... докт. филол. наук : 10.01.08. Самара, 2010. 434 с.

2. Роганова И. С. Исторические ракурсы в немецкоязычной литературе конца ХХ века. М. : ИПЦ «Глобус», 2007. 100 с.

3. Чугунов Д. А. Немецкая литература 1990-х: основные тенденции развития: дис. ... докт. филол. наук : 10.01.03. Воронеж, 2006. 413 с.

4. Adorno T. The Meaning of Working Through the Past. Critical Models: Interventions and Catchwords / trans. from German Henry W. Pickford. New York: Columbia University Press, 2005. P. 89-103. URL: https://signale.cornell. edu/text/meaning-working-through-past.

5. Bayer M. Flughunde. Frankfurt am Main : Suhrkamp, 1996. 302 S.

6. Epping-Jäger C. Stimmgewalt. Die NSDAP als Rednerpartei. Stimme / Hrsg. v. Sybille Krämer. Frankfurt am Main : Suhrkamp, 2006. S. 147-171.

7. Grass G. The Tin Drum / trans. from German by R. Manheim. London : Vintage, 2004.

8. Habermas J. Eine Art Schadensabwicklung. Die Zeit. 11.07.1986. URL: http://www.zeit.de/1986/29/eine-art-schadensabwicklung/.

9. Hage V. Feuer vom Himmel. Der Spiegel. 12.01.1998. URL: http://www.spiegel.de/spiegel/print/d-7810012.html.

10. Herrmann M. Vergangenheit. Erzählen von Nationalsozialismus in der deutschen Literatur seit den neunziger Jahren. Würzburg : Königshausen \& Neumann, 2010. 320 S.

11. Jesse E. Doppelte Vergangenheitsbewältigung in Deutschland. Vergangenheitsbewältigung / Hrsg. von E. Jesse, K. Löw. Berlin, 1997. S. 11-26.

12. Karasek H. Schreien und Flüstern. Helmut Karasek über Marcel Beyers Roman «Flughunde». Der Spiegel. 03.07.1995. URL: http://www.spiegel.de/ spiegel/print/d-9201442.html. 
13. Künzig B. Schreie und Flüstern - Marcel Beyers «Flughunde». Baustelle Gegenwartsliteratur. Die neunziger Jahre / Hrsg. v. A. Erb. Opladen/ Wiesbaden : Westdeutscher Verlag, 1998. S. 122-153.

14. Marcel Beyer: Flughunde [Rezension]. FAZ. 17.03.2002. URL: http://www.faz.net/aktuell/feuilleton/buecher/rezensionen/belletristik/rezensionbelletristik-marcel-beyer-flughunde-152244.html.

15. Metzler Literatur Lexikon: Begriffe und Definitionen / Hrsg. von D. Burdorf, Chr. Fasbender, B. Moennighoff. Stuttgart, Weimar : Verlag J. B. Metzler, 2007. 845 S.

16. Nolte E. Die Vergangenheit, die nicht vergehen will. Eine Rede, die geschrieben, aber nicht gehalten werden konnte. Frankfurter Allgemeine. 6.06.1986. URL: http://www.staff.uni-giessen.de/ g31130/PDF/Nationalismus/ ErnstNolte.pdf.

17. Ostrowicz Ph. A. Die Poetik des Möglichen. Das Verhältnis von „historischer Realität“ und „literarischer Wirklichkeit“ in Marcel Beyers Roman „Flughunde“. Stuttgart : ibidem-Verlag, 2005. 130 S.

18. Rilke R. M. : Werke in 3 Bänden. Frankfurt am Main : Insel Verlag, 1966. Band 3. Prosa. 597 S.

19. Sebald W. G. Luftkrieg und Literatur. München; Wien : Hanser Verlag, 1999. $166 \mathrm{~S}$.

20. Simon U. Assoziation und Authentizität. Warum Marcel Beyers Flughunde auch ein Holocaust-Roman ist. Auskünfte von und über Marcel Beyer. Fußnoten zur Literatur. Heft 46. Bamberg, 2003. S. 126-145.

21. Strebin B. Wenn die Stimme die Seele (z)ersetzt ... Marcel Beyer über seinen Roman „Flughunde“. GrauZone. Zeitschrift über neue Literatur. 1995. № 5.

22. Uecker M. «Uns allen steckt etwas von damals in den Knochen». Der Nationalsozialismus als Objekt der Faszination in den Romanen Marcel Beyers. Wende des Erinnerns? Geschichtskonstruktionen in der deutschen Literatur nach 1989 / Hrsg. v. B. Beßlich, K. Grätz, O. Hildebrand. Berlin : Erich Schmidt Verlag, 2006. S. 53-68.

23. Welzer H. Vergangenheitsüberwältigung. Kultur des Erinnerns. Vergangenheitsbewältigung in Spanien und Deutschland / Hrsg. v. I. Olmos, N. Keilholz-Rühle. Frankfurt am Main : Vervuert, 2009. S. 29-32.

\section{Information about the author:} Pomohaibo J. O.

Candidate of Philological Sciences, Assistant Professor,

Department of Foreign Literature, Odessa I. I. Mechnikov National University 2, Dvoryanska str., Odessa, 65082, Ukraine 